\title{
Political Leaders in the APP Ecosystem
}

\author{
Raquel Quevedo-Redondo ${ }^{1}(\mathbb{D})$, Nuria Navarro-Sierra ${ }^{2, *} \mathbb{D}$, Salome Berrocal-Gonzalo ${ }^{1}$ \\ and Salvador Gómez-García ${ }^{1}$ (D)
}

1 Department of Early Modern History, Modern History and History of America, Journalism and Audiovisual Communication and Advertising, Faculty of Philosophy and Literature, University of Valladolid, 47011 Valladolid, Spain; raquel.quevedo.redondo@uva.es (R.Q.-R.); salomeb@hmca.uva.es (S.B.-G.); salvadorgomez@hmca.uva.es (S.G.-G.)

2 Department of Communication and Sociology, Faculty of Communication Sciences, Rey Juan Carlos University (URJC), 28942 Madrid, Spain

* Correspondence: nuria.navarro.sierra@urjc.es

Citation: Quevedo-Redondo, Raquel, Nuria Navarro-Sierra, Salome Berrocal-Gonzalo, and Salvador Gómez-García. 2021. Political Leaders in the APP Ecosystem. Social Sciences 10: 307. https://doi.org/ 10.3390 /socsci10080307

Academic Editor:

Andreu Casero-Ripollés

Received: 30 June 2021

Accepted: 10 August 2021

Published: 13 August 2021

Publisher's Note: MDPI stays neutral with regard to jurisdictional claims in published maps and institutional affiliations.

Copyright: (c) 2021 by the authors. Licensee MDPI, Basel, Switzerland. This article is an open access article distributed under the terms and conditions of the Creative Commons Attribution (CC BY) license (https:/ / creativecommons.org/licenses/by/ $4.0 /)$.

\begin{abstract}
This article analyzes the process of symbolic and critical-discursive construction of applications developed for mobile devices for some of the world's most important heads of state through their manifestation in the ecosystem of mobile applications for iOS and Android. The sample includes 233 applications of 45 politicians from 37 countries. A content analysis-based method was applied to the discourse of these apps and users' comments. The results reveal the dominant discourses in this scenario and identify the characteristics that influence their popularity, the influence of viral content and their reception in the connection between the mobile ecosystem and the political sphere. The discourse on the apps reveals a commercial interest and the existence of a diffuse diffusion of political commitment in terms of entertainment, parody and virality.
\end{abstract}

Keywords: political communication; politicking; infotainment; mobile devices; digital communication

\section{Introduction}

The emergence of interactive and networked technologies is democratizing the construction and perception of social knowledge, the power structures in daily life, and civic and political engagement (Glas et al. 2019). In this way, seemingly innocuous content such as games about personalities from the political sphere for mobile devices can lead citizens to cross the fine line that today separates full political personalization from indiscriminate government spectacle that is not limited to strategic vote-catching (Berrocal 2003; Balmas and Sheafer 2013; Segado-Boj et al. 2015; López-Meri et al. 2020; Zamora Medina et al. 2021).

This scenario raises the question of the utility of apps to enhance electoral engagement with those who hold or aspire to positions of power. On the one hand, it is assumed that while political information is ubiquitous on the internet, people under the age of 25 are not interested in it because of the traditional framework on which it is built. In this context, it seems possible that applications that focus on entertainment may solve part of the above problem. However, researcher Tamara Small points out the risk of assuming that young people will be attracted to content simply because it is published in a familiar and easily accessible interface (Scherer 2016).

With this in mind, this study aims to explore the characteristics of mobile device app use in political discourse, both in terms of the features of leaders who manifest most and the ways in which app users receive this content. To achieve this, we take the "ludification of culture" (Raessens 2014) as a starting point for the different ways to achieve the so-called "pop politics" (Mazzoleni and Sfardini 2009) and its transmedial narration (Durántez-Stolle and Martínez-Sanz 2019). These factors contribute to the transfer of interest from the spectacularization of political activities to the development of new mobile applications 
(Shankland 2008; Tau 2012; Vázquez-Sande 2016; Gómez-García et al. 2019; Navarro-Sierra and Quevedo-Redondo 2020; Zamora-Medina et al. 2020; Cervi and Marín-Lladó 2021).

The objective of this study is to analyze the construction of some of the main global leaders through their manifestation in the ecosystem of mobile entertainment applications for iOS and Android. In other words, the aim is to explore the sphere of contemporary "gamecracy" or "gamocracy" (Gekker 2012) and to explore a new way of engaging with government, as well as to reflect on the "casual politicking" (Gekker 2019) that is currently driving a different kind of engagement.

\subsection{Politainment and Spectacularization}

From an eminently theoretical point of view, for authors such as Raymond Williams (1993), there are four common uses of the term "popular". Therefore, this term is understood not only as that which attracts the interest of a large number of people but also as anything that we consider rather frivolous or light, that deliberately tries to captivate the masses and the forms of culture created by individuals—such as "emirecs", understood as people who send out and receive digital content (Aparici and García-Marín 2018) or groups for the enjoyment of the citizenry. These meanings are embedded into some of the main approaches to popular culture (Grindstaff 2008; Martín-Quevedo et al. 2019), which not only encompass several objects of study but also tend to consider "pop" as something imposed from outside.

Since the 1980s, there has been an inclination to believe that there are external actors who promote the penetration of an "inauthentic" commercial culture "for the people" and "totally controlled" (Bennett 1986) to exploit the benefits of "soft power" (Nye 1990) and to direct the interest of the population towards its real goal. This goal may be to win votes, satirize a government leader through memes or television parodies, or simply to fire up the "political fandom" (Highfield et al. 2013; Dean 2017; Penney 2017; Quevedo-Redondo and Portalés-Oliva 2017). This phenomenon is understood as a mixture of curiosity about institutions and a predisposition to practice the cult of celebrity (Penney 2017).

With the wide range of apps that, according to Vázquez-Sande, are useful for parties and candidates when they rely on "gamification" (Vázquez-Sande 2016), it is possible to stimulate segments of "soft voters" (Kenski et al. 2010), inform users about outstanding events or even increase the popularity of certain rulers. Regardless of the purpose for which creative audiences develop applications apart from professional political strategies, when talking about mobile devices as a means of mass communication (Ahonen 2008), they refer to tools that enable the successful attraction of the desired audience through direct, viral, relational, interactive, promotional and location-based content as a "key element of one-to-one marketing" (Gómez-Tinoco 2010, p. 246).

As argued by politainment researchers such as Street (1997), Wheeler (2013) or Berrocal (2017), spectacularization is one way to bring the message closer to apathetic citizens who are not interested in the future of government. So, personalization promoted by the app ecosystem is expected to add a dimension over time that is more engaging, entertaining and directly relates to the mainstream culture disseminated by mass media (Martel 2011). In this way, social science researchers find an emerging line in gamification that looks towards a utilitarian line: serious games. In this sense, the combination of casual games, aimed at a wide audience (Juul 2010; Gekker 2019), and newsgames (Gómez-García et al. 2021) stand out to promote the discussion of controversial issues. All this, without forgetting that the design of these products not only meets the entertainment needs of the audience, but also provides them with a completely new experience that encompasses everything from decision-making to cognitive processes. (Wan and Shao 2019).

Newsgames present information in an "interesting and authentic" way, which is why Wan and Shao (2019) argue that through them, audiences finally pay more attention to government affairs and become closer to both those in power and the mainstream media. With this in mind, and without going into the evaluation of video games in which the player is simply trying to make fun of a political party or perform "cathartic" acts (López-DeAnda 
and Cedeño-Navarro 2014), two types of studies support the framework of reference of this research:

1. Descriptive contributions based on app analysis and the gamification of politics (Gutiérrez-Rubí 2014; Vázquez-Sande 2016; Gómez-García et al. 2019; Gil-Torres et al. 2020).

2. Work that aims to introduce concepts such as "gamocracy" or "politicking" into academia, which have so far found little acceptance (Gekker 2012, 2019; NavarroSierra and Quevedo-Redondo 2020; González-González and Navarro-Adelantado 2021). These concepts are inspired by the intention to promote political engagement through playful agency.

This article belongs to the first category, after completing the revision that made it possible to narrow down the antecedents of this research and connect it to the phenomenon of political personalization.

\subsection{From Apps to Casual Politicking}

The increasing visibility of political app use is something that authors such as Shankland (2008) and Tau (2012) have noted in the presidential campaigns that Barack Obama led in 2008 and 2012. These analyses are complemented by others who focus interpretive efforts on activism and turnout and political satire (Kleina 2020). As Vázquez-Sande observes in his study of the use of these applications in Spain, 20\% of them have a "ludic-parodic" goal (2016), compared to those created for informative purposes, those intended to allow direct communication between candidates and voters, those designed to provide "civic value" (Sandoval-Almazán et al. 2012), and those simply intended to share news about a particular political party.

Studies such as those by Rojas and Puig-i-Abril (2009), Campbell and Kwak (2011), Kim et al. (2016) and Yamamoto et al. (2018) provide evidence of the political utility of news consumption via mobile devices and even point to the emergence of a new "media logic" (Klinger and Svensson 2015). However, this plethora of works anchored in modernity does not address in depth all the possibilities that technopolitics offers to capture the interest of Millennials (López Vidales and Rubio 2021), a generation that wants a more "promiscuous, demanding and volatile" experience with formal politics (Gutiérrez-Rubí 2015).

At the beginning of the twenty-first century, research on mobile applications can still be considered an emerging field of research (Light et al. 2016), and although gamification permeates all fields, there is still much to be conducted at the academic level in the area that concerns us.

As Gutiérrez-Rubí (2014) explains, "politics is not a game, but playing is a natural way of learning and knowing". Games and creativity are motivators for voting; they call on voters to become more informed and mobilize young and urban citizens. Both this segment of voters and the over-25 s are aware that applications have undeniable benefits in promoting a new "politics for the pocket [ . . . ] described as ubiquitous, nonstop, personalized, multichannel, traveling and fast" (Vázquez-Sande 2016).

Researcher Alex Gekker (2019) is the first to compare games that enable "casual" games - those without long sessions or the requirement of unconditional commitment-to game-based apps inspired by leaders and political parties from around the world. Gekker calls this new dimension "casual politicking", exploring how citizens are drawn to election messaging when it is presented informally, with features of gamification and without excessive involvement from anyone who downloads the app on their phone (Table 1). 
Table 1. Proposal for a comparison between the principles of participation in "casual games" and "casual politicking".

\begin{tabular}{|c|c|}
\hline Casual Gaming & Casual Politicking \\
\hline $\begin{array}{l}\text { Key priority for developers/Juiciness: visual } \\
\text { and auditory gratification is prioritized based } \\
\text { on the simplification of tasks and a clear } \\
\text { definition of the objectives of the game. }\end{array}$ & $\begin{array}{l}\text { Key priority for developers/Intuitive } \\
\text { interfaces: design patterns help increase the } \\
\text { usability of the product with solutions known } \\
\text { to users who find the app reliable and } \\
\text { attractive for immediate interaction. }\end{array}$ \\
\hline $\begin{array}{l}\text { Prevalence of simplicity/Low interruptibility: } \\
\text { simple gameplay is offered in short bursts to } \\
\text { avoid saving games. }\end{array}$ & $\begin{array}{l}\text { No prevalence of simplicity/Issue-centered: } \\
\text { action focused on the theme of the game } \\
\text { instead of ideology, thus achieving an } \\
\text { engagement supported by entertainment on } \\
\text { the political aspect. }\end{array}$ \\
\hline $\begin{array}{l}\text { Without penalty/Indulgence: apps designed } \\
\text { for gamers to avoid going too far back in the } \\
\text { gaming experience if they make mistakes. }\end{array}$ & $\begin{array}{l}\text { Penalty/Low penalty: fast recovery in case of } \\
\text { failure in the game to increase the number of } \\
\text { possible players. }\end{array}$ \\
\hline $\begin{array}{l}\text { Social impetus: tendency to foster social } \\
\text { connections within the game, either by making } \\
\text { the game multiplayer, creating leader boards or } \\
\text { offering bonuses/points for inviting friends. }\end{array}$ & $\begin{array}{l}\text { Social impetus: the bonds that are created are } \\
\text { an important part of the participatory } \\
\text { experience, which underlines fun over } \\
\text { ideology. }\end{array}$ \\
\hline
\end{tabular}

According to Antoni Gutiérrez-Rubí (2014), rulers and their teams have realized that casual games constitute a new space for action and communication due to their appeal, potential intergenerational use and acceptance among youth. Regardless of this observation, any study on politicking can help verify that the creators of a successful app do not need to maintain direct ties to political parties or governments. Ideological interests are put aside, and the focus is on entertainment through the application of seven keys (Figure 1).

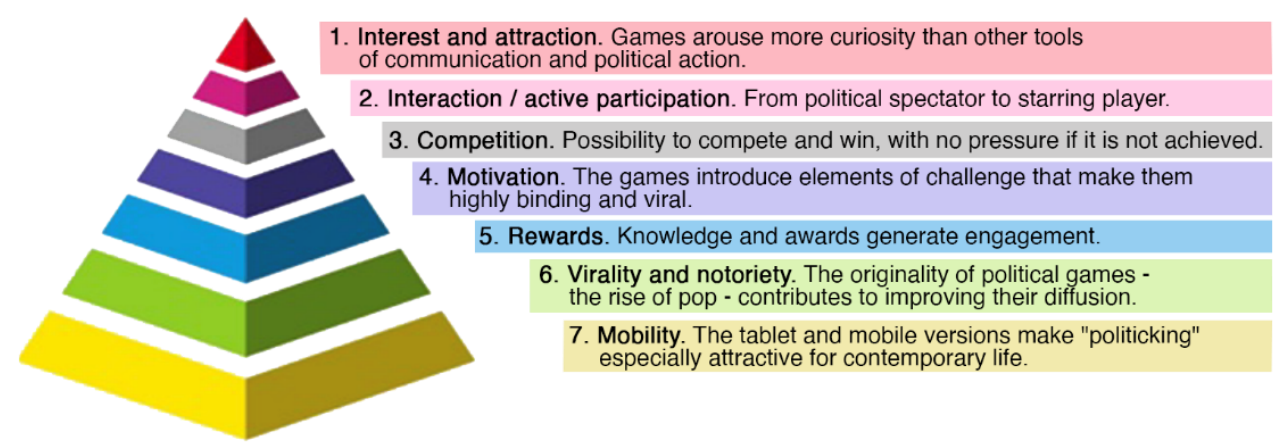

Figure 1. Keys to the success of a casual politicking app. Source: Navarro-Sierra and QuevedoRedondo (2020) on contributions from Gutiérrez-Rubí (2014, p. 40).

Given the outlined ecosystem of apps, this proposal contributes to make visible an emerging line of research on the so-called "gamocracy" (Gekker 2012). In other words, it is a form of political engagement characterized by playful agency via interfaces reminiscent of games in the modern era, and it combines several of the elaborations described with those of political personalization, which distinguishes the desacralization of power from trivialization at any cost.

The candidate for a position that aspires to become a "message through his/her image" (Rebolledo 2017) knows that (s)he must strive to do so with the awareness that opportunities can become threats, and that when this phenomenon and that of popularization coincide on the fringes of populism, the loss of the trust or apparent credibility that any candidate exudes is a likely cost. In the field of casual politicking and given that content creators are usually independent companies or individuals motivated by economics rather than 
ideology (Navarro-Sierra and Quevedo-Redondo 2020), the purpose of entertainment without the involvement or consent of the powerful cancels out much of the risk if the audience does not like the entertainment. As with cartoons, only with an idea of the political as object and purpose, less linked to a "referential conflict" or a "triggering event" (López-DeAnda and Cedeño-Navarro 2014), and with some functions of reinforcement of imaginaries more linked to characters than to contexts.

\section{Objectives}

The aim of the present investigation can be determined based on these coordinates. Specifically, it aims to explore how mobile applications have built a discourse on the main political leaders of the European Union, United Kingdom and Latin America (37 countries) in the last decade. The inspiration comes from previous research about Donald Trump in the app ecosystem (Gómez-García et al. 2019), and, therefore, the former American president is excluded from the sample. In this way, the present study aims to find out the characteristics that distinguish this content and how the apps are received through an investigation that aims to answer two specific questions:

Research Question 1. What discourse do the apps suggest in relation to the political leaders of the countries that make up the sample between 2013 and 2020?

Research Question 2. How are these apps received and what is the likely effectiveness (or level of agreement) of their users with the main discourse?

Using the analytical method described in the following section, the goal is to answer both questions and identify the additional dimensions of personalization of political leadership in the mobile app ecosystem.

\section{Materials and Methods}

The analysis sample included all apps linked to executive leaders $(n=45)$ of the countries that made up the sample $(n=41)$ using Google Play and Apple Store browsers. The search was extended to the website Sensor Tower, an online tool for monitoring apps, and different keywords were used combining names, first names or nicknames of the political leaders and countries that formed the sample. Only the apps that were directly related to the political figure of one of these politicians were considered in the selection. The final sample $(n=233)$ included apps with a release date between 10 May 2011 and 4 April 2020, whose language was either known to the researchers or easily understood using automatic translation services. All authors participated using a quantitative content analysis coding sheet (Table 2) developed and refined in previous research (Riffe et al. 2014; Krippendorff 2018; Gómez-García et al. 2019; Navarro-Sierra and Quevedo-Redondo 2020).

All selected apps were coded using three sets of variables which aimed to answer the research questions. The first set of formal variables facilitated their identification or collected the data offered by the platforms consulted (application name, operating system, launch date, publisher, number of downloads, user ratings, among others).

The second set of variables surrounds RQ1 to identify the distinctive characteristics of application developers (Wang et al. 2017) and the discourse models used in other studies (Haigh and Heresco 2010; Gómez-García et al. 2019). The latter are categorized as "escapist" (discourses that have no relation to reality and propose an unreal or purely viral construction); "circumstantial" (the popularity of the character is used but without proposing a complementary construction); "informative" (information about the politician's activities is provided, for example, during the election campaign); "intentional" (when an evaluation of the leader is intended); "satirical" (emotional elements are highlighted with ironic intent). The last variable in this group includes ideological attitude, which determines whether the evaluation of the political figure or his actions are positive, negative or neutral. 
Table 2. Code sheet for app analysis.

\begin{tabular}{|c|c|}
\hline \multicolumn{2}{|r|}{ Identification Data } \\
\hline App's name & [Name] \\
\hline Platform/OS & Android/iOS/both \\
\hline Launch date & [Day/Month/Year] \\
\hline Developer's country & [Name] \\
\hline Downloads (estimated) & [Number] \\
\hline Most popular country & [Name] \\
\hline Price & Free/Ads/In-app purchases/xx $€$ \\
\hline Genre & Game/Social/Business/Entertainment/Communication \\
\hline Discourse type & Escapist/Circumstantial/Informative/Intentional/Satirical \\
\hline Description & App description from store page \\
\hline Main character & [If any: Name] \\
\hline Adversaries & [If any: Name] \\
\hline Ideological positioning & Positive/Neutral/Negative \\
\hline \multicolumn{2}{|r|}{ Development Characteristics } \\
\hline Developer & [Name] \\
\hline Total apps launched & [Number] \\
\hline Profile & Professional/Commercial/Casual/Ideological \\
\hline \multicolumn{2}{|r|}{ User's Feedback } \\
\hline Number of votes & [Number] \\
\hline Rating & [Votes in each position, scale 1 to 5 ] \\
\hline Number reviews & [Number] \\
\hline Reviews & [Text from store page] \\
\hline Others & [Free text] \\
\hline
\end{tabular}

Finally, the third group of variables is used to answer RQ2. For this purpose, user ratings and reviews were collected and analyzed from quantitative (number of opinions) and qualitative points of view (positioning towards the app and type of comment, linked to content, functionality, commitment to entertainment, etc.).

\section{Results}

\subsection{Political Popularity in Mobile Ecosystems}

The localization and coding process of the sample provided a first set of results that allow the identification of the most popular politicians in the mobile application ecosystem. In this sense, the number of apps available was interpreted as a popularity vector that allowed distinguishing between the most popular leaders in the mobile content ecosystem and those who are not. Table 3 shows the politicians who had five or more apps at the time of location and the selection of the sample ${ }^{1}$ (the shaded boxes reflect the years when they were not at the head of the executive branch of their country).

Table 3. Presence of the most popular politicians in the mobile ecosystem.

\begin{tabular}{cccccccccccc}
\hline Country & Leader & $\mathbf{2 0 1 3}$ & $\mathbf{2 0 1 4}$ & $\mathbf{2 0 1 5}$ & $\mathbf{2 0 1 6}$ & $\mathbf{2 0 1 7}$ & $\mathbf{2 0 1 8}$ & $\mathbf{2 0 1 9}$ & $\mathbf{2 0 2 0}$ & Total \\
\hline Brazil & J. Bolsonaro & 0 & 0 & 1 & 8 & 27 & 66 & 5 & 0 & 107 \\
\hline Germany & A. Merkel & 4 & 2 & 1 & 1 & 7 & 13 & 3 & 1 & 32 \\
\hline France & E. Macron & 0 & 0 & 0 & 0 & 13 & 8 & 2 & 2 & 25 \\
\hline Venezuela & N. Maduro & 1 & 1 & 4 & 1 & 2 & 3 & 3 & 2 & 17 \\
\hline \multirow{2}{*}{ The United Kingdom } & T. May & 0 & 0 & 0 & 0 & 2 & 5 & 0 & 0 \\
\cline { 2 - 11 } & B. Johnson & 0 & 0 & 1 & & 0 & 0 & 2 & 5 \\
\hline Spain & P. Sánchez & 0 & 2 & 0 & 2 & 0 & 1 & 3 & 0 \\
\hline Chile & S. Piñera & 0 & 0 & 0 & 1 & 1 & 1 & 2 & \\
\hline Czech R. & M. Zeman & 1 & 2 & 0 & 1 & 0 & 1 & 0 & 0 \\
\hline
\end{tabular}


The data reflects that the politicians with the greatest presence in the mobile app ecosystem responded to specific features that had an unequal impact on their popularity in this scenario: longevity in office, media profile, political actions, informational agenda and international importance of the country. Almost all analyzed apps were developed during the performance as head of the country's executive branch, but sometimes in conjunction with intense electoral activity, as with Jair Bolsonaro and the 2018 presidential elections in Brazil.

This combination allows the announcement of the recurrence of two political styles, with some nuances, in the app distribution platforms. On the one hand, we would speak of the popularity of "controversial" profiles and, on the other hand, of institutional profiles that are long-lived or associated with countries that have a significant impact on economic and international politics.

The data in Table 3 clearly identifies the most prominent figure: Brazilian President Jair Bolsonaro. His controversial media popularity and belligerent political activity place him in populist coordinates, to which the app ecosystem had responded in a similar way to the former USA President Donald Trump, both in terms of production discourse and characteristics (Gómez-García et al. 2019). Apps linked to Venezuelan President Nicolás Maduro and Czech President Miloš Zeman fall into the same logic, albeit to a lesser extent.

Political leaders who stand out in the institutional sphere or because of their countries geopolitical footprint are linked to German Chancellor Angela Merkel and French President Emmanuel Macron. Needless to say, the most popular European heads of state do not reach Bolsonaro's numbers but their presence is significant, as we will see, due to the volume of their app downloads.

The remaining heads of state listed in Table 3 (UK, Spain and Chile) are halfway between the previous two profiles. On the one hand, there are significant states on the international stage that have also recently been spurred by political interventions and a complex media agenda (Brexit in the UK; no-confidence vote and problems forming government in Spain; social unrest faced by Chile's president).

\subsection{Political Personalization in the Mobile Ecosystem}

The public personality traits of political leaders in the mobile ecosystem have been associated with the type of content developed for each of them. Thus, the distribution shown in Figure 2 provides significant correspondences between the political profiles and the content developed for each of them.

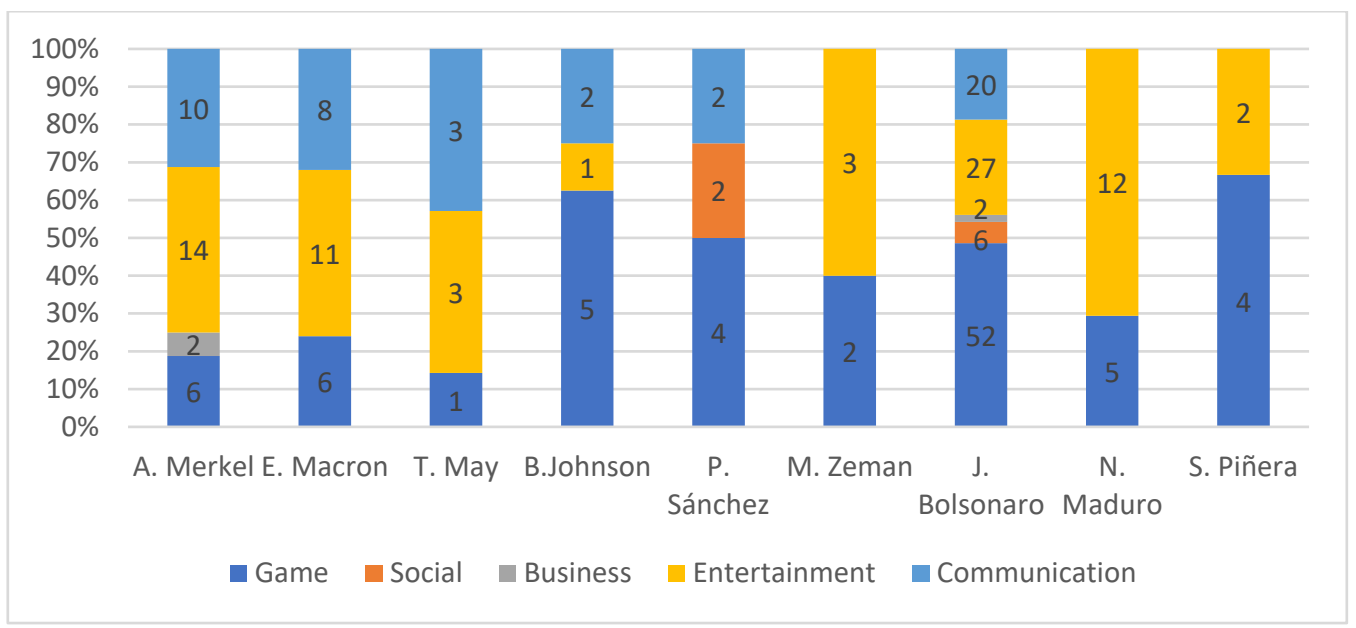

Figure 2. Classification by categories according to platforms. Source: own elaboration. 
The political profiles of Angela Merkel and Emmanuel Macron respond from a quantitative perspective to a much more corporate and less controversial reality than those of their counterparts in other countries. To be precise, a certain balance is identified between the different types of apps and a proportion of games that ranges between 18 and $24 \%$. This data-the percentage of games-are related to the fact that game-based content usually has high satirical content. However, the entertainment section implies a desire to integrate these political figures into discourses, since they consist mainly of stickers and soundboards that allow their interaction with messaging tools such as WhatsApp, Telegram or Facebook (among other social networks). In contrast, Boris Johnson and Jair Bolsonaro have a significant presence of content framed in the "games" category.

The type of content offered by these games often also depends on the nature of the type of political profile. In these cases, for example, the games associated with leaders of the institutional profile correspond to a simple design that uses popular game mechanics such as Flappy Birds, Whac-A-Mole or Tic-Tac-Toe, with slight aesthetic variations that hardly develop a government-like discourse (Scheme 1a,b). Conversely, games involving Jair Bolsonaro, Nicolas Maduro or Boris Johnson are more critically loaded in terms of the controversies with which they are associated. Recurring, therefore, are the bellicose connotations of the presidential election as used by Bolsonaro in 2019 (Scheme 1d), the debate around Brexit (Scheme 1c) or the international controversies of Nicolas Maduro.

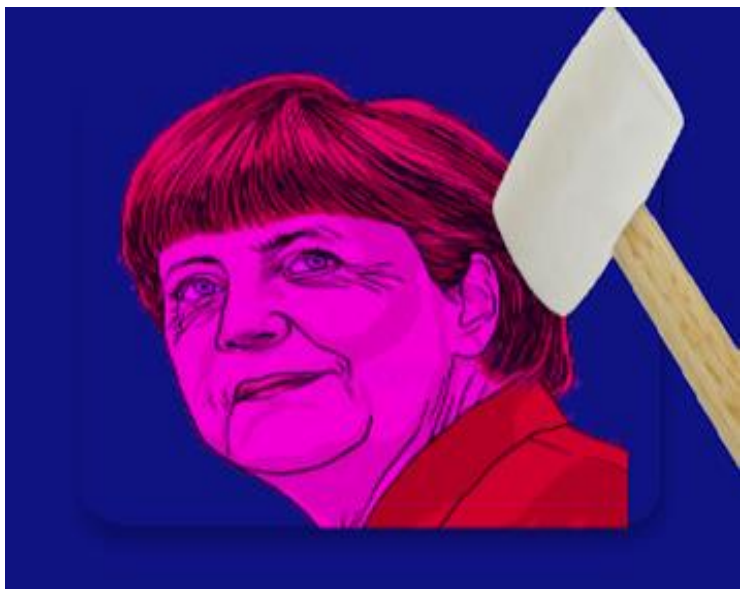

(a)

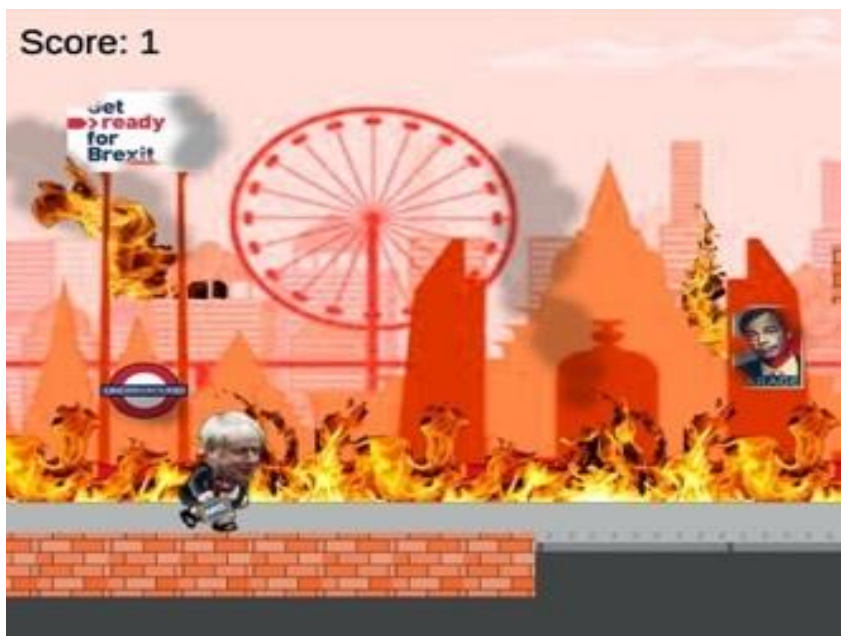

(c)

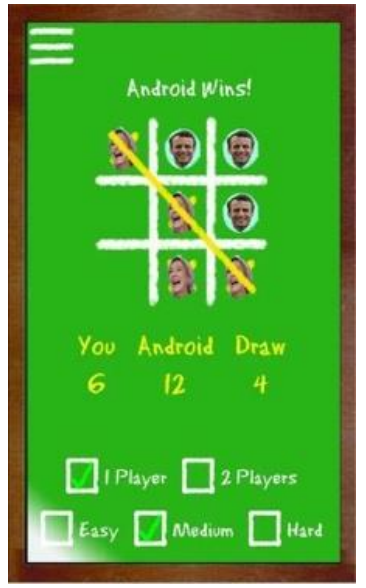

(b)

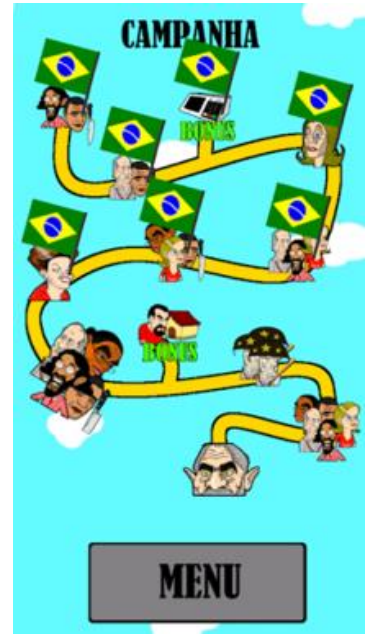

(d)

Scheme 1. Manifestation of politicians in popular apps. Source: the respective applications. (a) Merkel Tap (Presovsky 2018). (b) Macron vs. Le Pen Tic Tac (haijoubdemo 2017). (c) Brexit Run (Karma Skid 2020). (d) Bolsonaro vs. Petralhada (Irmões Bródi 2018). 
The practical absence of official apps to manage the public activities of the different governments is not an obstacle for some to present themselves as such without being. In some cases, this responsibility lies on the political parties to which the head of government belongs (e.g., in Spain, France or Germany). A trend only broken by the former Maltese president Joseph Muscat, who uses his own official apps (developed by his party) as a communication channel.

The previous data are ratified with the analysis of the narrative proposals of the applications. These discourses are dominated by a circumstantial tone with Angela Merkel (58.3\%), Emmanuel Macron (45.8\%) and Theresa May (57.1\%), while in the case of Miloš Zeman it is divided between circumstantial and intentional (40\%). Finally, the informative type predominates in those related to Pedro Sánchez $(55.5 \%)$ and the satirical in those associated with Sebastián Piñera (66.6\%), compared to the intentional (critical) and satirical nature that characterizes the content inspired by Boris Johnson (63.3\%) or Jair Bolsonaro (51.4\%). However, these data do not imply that these proposals are accepted by users. Therefore, the following section lists the most downloaded apps, which arouse greater interest among mobile device users.

The focus of these discourses on the reduced number of apps of a more editorial nature-such as the intentional ones-reflects a more neutral construction, by the developers, of all the characters. Thus, a strategy more related to the goal of making its creators visible within the platform, using viral techniques associated with political figures to achieve self-promotion. This is also evident when it is verified that the same company has developed apps of politicians from different countries. This perception is supported by the assessment they receive in the set of applications. In this context, the majority of European applications (around 90\%) show a neutral cut in the personalization of politicians compared to the South American context (69\%). The exceptions are registered in Spain and England, since in the apps dedicated to Boris Johnson and Pedro Sánchez, the negative or humorous construction reaches $55.5 \%$. It can be concluded that the patterns analyzed in the discourse model not only indicate a different political culture between the countries of the European Union and Latin America, but also the implementation of a creative culture that forms the backbone of a different ideological discourse in these countries.

\subsection{Downloads Rule! (Quantity and Type of Message)}

The above data sheds light on which leaders received the most interest in the platforms from developers. The conclusions that can be drawn in this regard are heterogeneous. However, it can be stated that the reach of these contents is limited by their reception, since the mere presence of the apps on the Google Play and Apple Store platforms does not determine their informative effectiveness, their scope or level of use. Table 4, therefore, lists the most popular apps according to the number of downloads estimated by Google Play (a dataset not provided by the Apple Store).

This data reveals some matters of interest. The first one is that it is feasible to specify the extent of the popularity of each of the leaders of the sample beyond the intentions of the developers of these contents ${ }^{2}$. In this scenario, for instance, the popularity of Jair Bolsonaro is not only specified in the number of apps developed, but also in the popularity of those contents, since seven of his apps exceeded 100,000 downloads. Such results make it possible to establish that the acceptance of certain politicians corresponds to their "success" in the mobile ecosystem. This is a reflection that ought to be placed in the field of action and within the framework of political personalization since the controversy associated with specific events such as Brexit or the difficulties of government formation in Spain do not in themselves raise these levels of popularity in the downloads. 
Table 4. Most popular apps on Google Play.

\begin{tabular}{|c|c|c|c|}
\hline Most Popular App(s) & Download Range & Type of App & Leader \\
\hline Stickers do Bolsonaro & $500,000-1,000,000$ & Stickers & Jair Bolsonaro \\
\hline A. Merkel Soundboard & $100,000-500,000$ & Soundboard & Angela Merkel \\
\hline Bolsonaro Voador & $100,000-500,000$ & Game & \\
\hline Bolsonaro-Áudios & $100,000-500,000$ & Soundboard & \\
\hline Bolsonaro vs. Petralhada & $100,000-500,000$ & Game & \\
\hline Bolsonaro Terror do PT & $100,000-500,000$ & Game & \\
\hline Brazilian Trump & $100,000-500,000$ & Meme stickers & \\
\hline Bolsonaro no WhatsApp & $100,000-500,000$ & Stickers & \\
\hline Maduro Mango Attack & $100,000-500,000$ & Game & Nicolás Maduro \\
\hline Miloš Zeman-HRA & $50,000-100,000$ & Game & Miloš Zeman \\
\hline Miloš Zeman-Quotes & $50,000-100,000$ & Soundboard & Miloš Zeman \\
\hline Piñera Stickers WhatsApp & $10,000-50,000$ & Stickers & Sebastián Piñera \\
\hline Macron Soundboard & $5000-10,000$ & Soundboard & Emmanuel Macron \\
\hline Pedro Sánchez Simulator & $5000-10,000$ & Game & Pedro Sánchez \\
\hline Boris Johnson Speaks! & $1000-5000$ & Soundboard & Boris Johnson \\
\hline Theresa May News & $50-100$ & Informative & Theresa May \\
\hline
\end{tabular}

Although most downloads come from the country of origin of each political leader, this is not the case for all apps (according to data provided by Sensor Tower). Thus, the United States is the country with the most downloads for several of Angela Merkel's apps. For example, Maduro Mango Attack is most popular with users in Colombia (which is not surprising given the number of Venezuelan immigrants in the country and the ironic tone of the game), and Theresa May News has the highest number of downloads in Kenya. While there are several fraudulent factors that can explain certain downloads (Dou et al. 2019), Kenyan users' interest in this political leader's news apps could be due to the trade relations between the UK and Kenya, as well as the British Prime Minister's visit to the African country in 2018 (EuroNews 2018). With this in mind and considering that not all downloads originate from the country they refer to, the actual impact of the apps can only be considered in general terms. Even if the apps of Zeman, whose country has a population of just over 10 million, have a higher ratio of downloads to population, it is uncertain whether this impact is a direct response to the president's popularity in his country.

Another crucial feature for the popularity of the apps is their free status, as they all fall into the freemium category, i.e., they are free for users and opt for monetization strategies based solely on their usage (mainly by displaying ads).

Table 3 also shows that the versions of popular games that employ politicians as characters and provide content for sharing on social networks (stickers or soundboards) are the models of apps that have the greatest acceptance among mobile device users, as noted in previous research (Gómez-García et al. 2019; Navarro-Sierra and Quevedo-Redondo 2020; Kleina 2020). This popularity is conditioned by the parodic and critical tone of the controversial leaders (Jair Bolsonaro or Nicolás Maduro), which in most cases elicits a critique of their most superficial and parodic features, without any deep criticism (for example, only $5.7 \%$ of the apps about Bolsonaro expressed outright negativity about him). Overall, the apps with a neutral evaluation of the leaders that make up Table 3 were mostly neutral $(68.3 \%)$, compared to those advocating a negative view $(28.2 \%)$ or, on the contrary, a positive view $(3.4 \%)$. 
The clear distribution shows the correlation between circumstantial and escapist discourses together with an ideological positioning that reveals an interest in using the figure of the politician to fulfil more commercial or self-promotional than ideological objectives. These coincidences reveal a simple logic in the creation of content aimed at virality (but not critique) and popular genres with slight aesthetic variations to achieve a maximum number of downloads in the shortest possible time.

Finally, the most characteristic feature of the analyzed applications is their contribution to an expressive line of political discourse that deals with the features of personalization of the most charismatic rulers, as shown in Scheme 2.

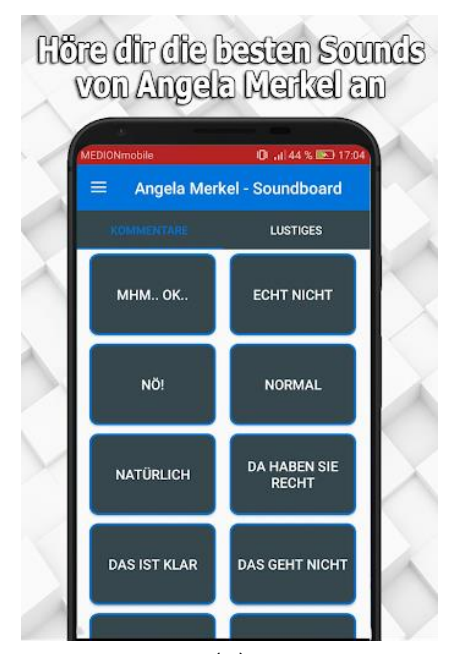

(a)

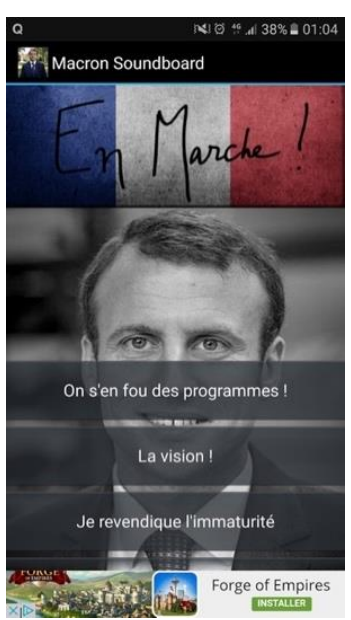

(b)

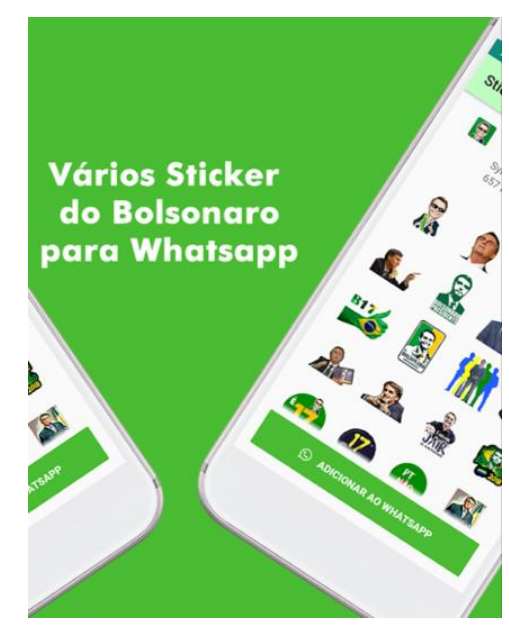

(c)

Scheme 2. Most downloaded apps of the sample. Source: the respective applications. (a) Angela Merkel Soundboard (Pentagames 2017). (b) Macron Soundboard (Wonderapply 2017). (c) Stickers do Bolsonaro (appssyncs 2018).

\subsection{A Polarized Reception}

The interpretation of the reception of the applications was made based on three variables of the analysis sheet: the number of votes (or ratings) received by each application, the rating or number of stars awarded (from 1 to 5) and their distribution and, finally, the analysis of the user reviews made on each application.

The joint analysis of the three variables shows that the most commented or those that received the highest score were related to games and/or entertainment and as well as those that were free for users.

The content of the applications, developed in the previous section, did not correspond in most cases to the intention that the coding sheet established to the developers. For example, $91 \%$ of the rating scores were either the minimum (1) or the maximum (5). This polarization suggests that the rating criterion depends more on the ideological or political positioning of the user than on the service or entertainment offered by the app. The comments each app receives have more to do with ideology than with the entertainment offered to the player, with promises such as the following: "Nothing is funnier than Angie's faces" (Angela Merkel Sticker für WhatsApp), "[ . . ] it is a fun reminder of the sad reality" (Miloš Zeman-HRA) or "That man is such an ass that they could put much more with stupidities or homophobic or preconceived phrases that he loves to say!!!" (Stickers do Bolsonaro).

In this sense, and in relation to the fieldwork carried out, the reaction of users to the applications corresponds to a very high percentage of their previous ideological beliefs without being changed by the professional, communicative or recreational services that the app offers. 


\section{Discussion and Conclusions}

The twenty-first-century voter assumes different profiles that are evident in the app ecosystem, from prosumer to emirec (Aparici and García-Marín 2018). In the context of this research, the new possibilities offered by digital media as communication spaces contribute, directly or indirectly, to playful forms of engagement with media politics (Ballesteros-Herencia 2020; Ballesteros-Herencia and Gómez-García 2020). This is another feature of "post-broadcast democracies" (Prior 2006), where citizens use the figures of the governmental sphere as "raw material" to fuel their creativity (Wilson 2011). This has been clear in the research that occupies these pages because, as outlined in the findings section, the popularity of leaders spurs the development of apps that are more focused on entertainment than on useful goals.

The good reception for mobile apps, which in some cases have been downloaded over 500,000 times, invites the academic community to reflect on the paucity of contributions on the relationship between gamification, political fandom and engagement. The reality challenges us to rethink this type of product as a tool without overlooking the fact that, as in the era of "pop politics" (Mazzoleni and Sfardini 2009) and in line with the review that enabled this research, the most requested content tends to have a significant amount of political personalization and parody.

The "political addicts" mentioned by Coleman (2003), whom Young (2010) refers to as "elite audiences", represent the type of audience that follows serious or hard news closely. It is a very sophisticated audience, but it cannot be representative of the general interest. In this sense, and at an international level, this article reveals that the number of apps with "informative discourse" is lower than those that follow circumstantial, satirical or purely intentional narrative proposals. This pattern highlights the existence of different political cultures between the countries of the European Union and those of Latin America, but also shows the implementation of a creative current that promotes a different ideological discourse depending on the state and the popularity of political leaders.

Finally, based on the coding and interpretation of 233 apps and against the backdrop of the outlined context, this paper presents conclusions that serve as answers to the main research questions. Thus, concerning the first question (RQ1), which sought an answer to the type of discourse proposed in apps in the context of the political leaders that formed the sample, it can be concluded that the presence of rulers in the mobile ecosystem and the number of apps that inspire them have different causes. The main reasons cited include political experience/longevity, geopolitical importance of the country, the respective leader rules and their media relevance. The explicit explanation refers to the fact that content creators are usually specialized companies or individuals rather than sporadic or moderate developers. As can be seen from the analysis conducted, economic motivations and self-promotion seem to drive the creative whirlwind, as the purpose to entertain and, consequently, to gain more downloads and advertisers prevails over contributions of an ideological nature. In other words, "issue-centricity" and "social impulse" are confirmed as characteristic features not only of casual politicking (Gekker 2019) but also of the business that drives this trend.

The rise of pop politics is one factor that explains why media figures such as Jair Bolsonaro, Nicolás Maduro or Boris Johnson, who fall into the category of "celebrity politicians" proposed by Street (2004), lead to a greater number of satirical intentionality games. In contrast, figures close to the so-called "political sophistication" (Luskin 1990) generate a type of discourse that is almost always informative or circumstantial. Escapist discourse associated with unreal or viral constructions manifests itself in popular proposals such as the games Tic-Tac-Toe with Macron's character or Whac-A-Mole with Merkel's face. This typology is not very representative, but it allows us to confirm the political keys proposed by Gutiérrez-Rubí (2014) and points to the simple game mechanics as a fundamental attraction of newsgames.

A final aspect related to this question lies in the projection of this type of content, which, according to the data in Table 3 , seems to have ended its phase of over-expectation 
for developers and is facing a downward curve in production. Future research could clarify whether this corresponds to a "valley of disenchantment" before consolidation, or whether other alternatives and habits have taken over the communicative space previously occupied by these apps.

The second research question (RQ2) of the study asked a more complex question than the previous one: the purpose was to measure the acceptance of the apps and the degree of adherence to their discourse. In this sense, and despite the limitations of the study, it was possible to carry out various verifications of the ideological positioning that emerges from the comments and evaluations of those who download the apps, since those who are neutrally evaluated by users represent a minority. In the Spanish case, for example, the tone towards Pedro Sánchez is decidedly negative. Such a result is recorded when the motivation of the app's creator is ideological (demanding freedom for "political prisoners" in Catalonia) and does not seek to inform or entertain, but rather to gain supporters for a cause by exploiting the amplification effect and the propensity for selective public exposure (Chaffee et al. 1977). A circumstance that occurs in the apps developed around the figure of the Brazilian president in a much more polarized logic: Jair Bolsonaro. Polarization thus has a place in a new space, showing that while application developers are not usually ideology-driven, the majority of consumers respond to this stimulus as they do in other media (Prada Espinel and Romero Rodríguez 2018; Masip et al. 2020; Romero-Rodríguez et al. 2021).

This work was not without limitations. First, the limitation related to specifying what counts as political participation in this process. We only looked at the notoriety of political leaders in the app ecosystem, but did not consider what part of the political realm we should place the development, downloading or interaction with an app in. Second, the overall aim of this research would benefit from an in-depth analysis of selected apps as a case study to offer their features, functions, design, origin, tone towards the leader, app store rating and some comments. Future research could consider the actual landscape to overcome these constraints and present a challenge for future research.

The entertainment options offered by mainstream politics preclude an "ideal democracy" scenario for "highly sophisticated" voters (Muñiz et al. 2018) but open new opportunities for average citizens with a different interest in what is happening in government. As with newsgames, mobile apps influence public opinion from the moment they help change the information and entertainment ecosystem. This leads to new kinds of engagement analysis, but also to satisfying questions such as the ones that guidethis research.

Author Contributions: Conceptualization S.G.-G.; methodology, R.Q.-R. and N.N.-S.; software, S.G.G.; validation, S.B.-G.; formal analysis, S.G.-G.; investigation, R.Q.-R., N.N.-S. and S.B.-G.; resources, S.G.-G. and N.N.-S.; data curation, N.N.-S.; writing-original draft preparation, R.Q.-R. and S.G.-G.; writing-review and editing, N.N.-S. and S.B.-G.; visualization, N.N.-S.; supervision, R.Q.-R. and S.B.-G. All authors have read and agreed to the published version of the manuscript.

Funding: This research is a preliminary result of R\&D\&I Research Project «Politainment in the face of media fragmentation: disintermediation, engagement and polarisation» (grant code PID2020114193RB-I00), funded by the Spanish Ministry of Economy, Industry and Competitiveness.

Conflicts of Interest: The authors declare no conflict of interest.

\section{Notes}

1 The rest of the leaders had a marginal presence, such as the case of Mark Rutte (Netherlands), Charles Michel (Belgium) Mauricio Macri (Argentina) and Sergio Matarella (Italy) with two apps. Another ten leaders of an executive branch only have one (V. Dancila, Romania; S. Löfven, Sweden; S. Niinistö, Finland; A. Tsipras, Greece; M.D. Higgings, Ireland; J. Muscat, Republic of Malta; A. Duda, Poland; M.R. de Sousa, Portugal; S. Kurz, Austria; B. Pahor, Slovenia).

2 The remaining leaders in the sample (those with fewer than five apps) did not have any outstanding dates. The most significant datum was the presence of the Greek president, Alexis Tsipras, and his only app Toí $\rho \alpha \varsigma$ Jumper (Koplax Studio, 2015). This game consisted in the president collecting as many coins as possible to cope with the economic crisis. It was in the range of 100-500 downloads. 


\section{References}

Ahonen, Tomi. 2008. Mobile as 7th of the Mass Media: Cellphone, Cameraphone, iPhone, Smartphone. Londres: FuturetexT.

Aparici, Roberto, and Diego García-Marín. 2018. Prosumers and emirecs: Analysis of two confronted theories. Comunicar 55: 71-79. [CrossRef]

Ballesteros-Herencia, Carlos A. 2020. Los marcos del compromiso: Framing y Engagement digital en la campaña electoral de España de 2015. Observatorio (OBS*) 14: 98-119. [CrossRef]

Ballesteros-Herencia, Carlos, and Salvador Gómez-García. 2020. Batalla de frames en la campaña electoral de abril de 2019. Engagement y promoción de mensajes de los partidos políticos en Facebook. Profesional De La Información 29. [CrossRef]

Balmas, Meital, and Tamir Sheafer. 2013. Leaders first, countries after: Mediated political personalization in the international arena. Journal of Communication 63: 454-75. [CrossRef]

Bennett, Toni. 1986. The Politics of the Popular and Popular Culture. In Popular Culture and Social Relations. Edited by Tony Bennett, Colin Mercer and Janet Woollacott. Philadelphia: Open University Press, pp. 6-21.

Berrocal, Salomé. 2003. Personalización de la Política. In Comunicación Política en Televisión y Nuevos Medios. Edited by Salomé Berrocal. Barcelona: Ariel, pp. 55-79.

Berrocal, Salomé. 2017. Politainment, la política espectáculo y su triunfo en los medios de comunicación. In Politainment. La Política Espectáculo en los Medios de Comunicación. Edited by Salomé Berrocal. Valencia: Tirant lo Blanch, pp. 37-52.

Campbell, Scott W., and Nojin Kwak. 2011. Political involvement in 'Mobilized' society: The interactive relationships among mobile communication, network characteristics, and political participation. Journal of Communication 61: 1005-24. [CrossRef]

Cervi, Laura, and Carles Marín-Lladó. 2021. What are political parties doing on TikTok? The Spanish case. Profesional De La Información 30: 1-17. [CrossRef]

Chaffee, Steven H., Marilyn Jackson-Beeck, Jean Duvall, and Donna Wilson. 1977. Mass Communication in Political Socialization. In Handbook of Political Socialization. Edited by Stanley Allen Renshon. New York: Free Press, pp. 223-58.

Coleman, Stephen. 2003. A tale of two houses: The House of Commons, the Big Brother House and the people at home. Parliamentary Affairs 56: 733-58. [CrossRef]

Dean, Jonathan. 2017. Politicising fandom. The British Journal of Politics \& International Relations 19: 408-24. [CrossRef]

Dou, Yingtong, Weijian Li, Zhirong Liu, Zhenhua Dong, Jiebo Luo, and Philip S. Yu. 2019. Uncovering Download Fraud Activities in Mobile App Markets. Paper presented at 2019 IEEE/ACM International Conference on Advances in Social Networks Analysis and Mining (ASONAM), Vancouver, BC, Canada, August 27-30; pp. 671-78. [CrossRef]

Durántez-Stolle, Patricia, and Raquel Martínez-Sanz. 2019. El politainment en la construcción transmediática de la imagen del personaje político. Communication \& Society 32: 111-26. [CrossRef]

EuroNews. 2018. Theresa May Viaja a África para Encontrar Nuevas Oportunidades para el Comercio Británico. Euronews. Available online: https: / / es.euronews.com/2018/08/28/theresa-may-viaja-a-africa-para-encontrar-nuevas-oportunidades-parael-comercio-britanico (accessed on 24 June 2021).

Gekker, Alex. 2012. Gamocracy: Political Communication in the Age of Play. Master's thesis, Utrecht University, Utrecht, The Netherlands.

Gekker, Alex. 2019. Playing with Power: Casual politicking as a new frame for political analysis. In The Playful Citizen: Civic Engagement in a Mediatized Culture. Edited by René Glas, Sybille Lammes, Michiel de Lange, Joost Raessens and Imar de Vries. Amsterdam: Amsterdam University Press, pp. 387-419.

Gil-Torres, Alicia, Juan Martín-Quevedo, Salvador Gómez-García, and Cristina San José-De la Rosa. 2020. The Coronavirus in the mobile device ecosystem: Developers, discourses and reception. Revista Latina Comunicación Social 78: 329-58. [CrossRef]

Glas, René, Sybille Lammes, Michiel de Lange, Joost Raessens, and Imar de Vries. 2019. The playful citizen: An introduction. In The Playful Citizen: Civic Engagement in a Mediatized Culture. Edited by René Glas, Sybille Lammes, Michiel de Lange, Joost Raessens and Imar de Vries. Amsterdam: Amsterdam University Press, pp. 9-30.

Gómez-García, Salvador, Alicia Gil-Torres, José Agustín Carrillo-Vera, and Nuria Navarro-Sierra. 2019. Constructing Donald Trump: Mobile apps in the political discourse about the President of the United States. Comunicar 59: 49-59. [CrossRef]

Gómez-García, Salvador, María Antonia Paz-Rebollo, and José Cabeza-San-Deogracias. 2021. Newsgames against hate speech in the refugee crisis. Comunicar 67: 123-33. [CrossRef]

Gómez-Tinoco, Alicia. 2010. El Mobile Marketing como estrategia de comunicación. Icono 8: 238-60. [CrossRef]

González-González, Carina, and Vicente Navarro-Adelantado. 2021. The limits of gamification. Convergence 27: 787-804. [CrossRef]

Grindstaff, Laura. 2008. Culture and Popular Culture: A Case for Sociology. The ANNALS of the American Academy of Political and Social Science 619: 206-22. [CrossRef]

Gutiérrez-Rubí, Antoni. 2014. Tecnopolítica. El uso y la Concepción de las Nuevas Herramientas Tecnológicas Para la Comunicación, la Organización y la Acción Política Colectivas. Barcelona. Available online: www.gutierrez-rubi.es (accessed on 24 June 2021).

Gutiérrez-Rubí, Antoni. 2015. La generación Millennials y la Nueva política. Revista de Estudios de Juventud 108: 161-69. Available online: https: / / bit.ly/3h2Dh5d (accessed on 24 June 2021).

Haigh, Michel M., and Aaron Heresco. 2010. Late-night Iraq: Monologue joke content and tone from 2003 to 2007. Mass Communication E Society 13: 157-73. [CrossRef]

Highfield, Tim, Stephen Harrington, and Axel Bruns. 2013. Twitter as a technology for audiencing and fandom: The \#Eurovision phenomenon. Information, Communication \& Society 16: 315-39. [CrossRef] 
Juul, Jesper. 2010. A Casual Revolution: Reinventing Video Games and Their Players. Cambridge: The MIT Press.

Kenski, Kate, Bruce W. Hardy, and Kathleen Hall Jamieson. 2010. The Obama Victory. How Media, Money, and Message Shaped the 2008 Election. New York: Oxford University Press.

Kim, Yonghwan, Hsuan-Ting Chen, and Yuan Wang. 2016. Living in the smartphone age: Examining the conditional indirect effects of mobile phone use on political participation. Journal of Broadcasting E Electronic Media 60: 694-713. [CrossRef]

Kleina, Nilton Cesar Monastier. 2020. De herói de jogos a adesivo no WhatsApp: Da imagem de Jair Bolsonaro retratada em aplicativos para celular. Revista Mediação 22: 42-51.

Klinger, Ulrike, and Jakob Svensson. 2015. The emergence of network media logic in political communication: A theoretical approach. New Media E Society 17: 1241-57. [CrossRef]

Krippendorff, Klaus. 2018. Content Analysis: An Introduction to its Methodology. Thousand Oaks: Sage Publications.

Light, Ben, Jean Burgess, and Stefanie Duguay. 2016. The walkthrough method: An approach to the study of apps. New Media E Society 20: 881-900. [CrossRef]

López Vidales, Nereida, and Leire Gómez Rubio. 2021. Tendencias de cambio en el comportamiento juvenil antes los media: Millenials vs. Generación Z. Estudios Sobre el Mensaje Periodístico 27: 543-52. [CrossRef]

López-DeAnda, Magdalena, and Miguel Cedeño-Navarro. 2014. El videojuego político en México como género editorializado para la exhibición, burla y toma de postura del quehacer de los políticos. Caleidoscopio 30: 73-111. [CrossRef]

López-Meri, Amparo, Silvia Marcos-García, and Andreu Casero-Ripollés. 2020. Estrategias comunicativas en Facebook: Personalización y construcción de comunidad en las elecciones de 2016 en España. Doxa Comunicación 30: 229-48. [CrossRef]

Luskin, Robert C. 1990. Explaining political sophistication. Political Behavior 12: 331-61. [CrossRef]

Martel, Fréderic. 2011. Cultura Mainstream. Cómo Nacen los Fenómenos de Masas. Madrid: Taurus.

Martín-Quevedo, Juan, Erika Fernández-Gómez, and Francisco Segado-Boj. 2019. How to Engage with Younger Users on Instagram: A Comparative Analysis of HBO and Netflix in the Spanish and US Markets. International Journal on Media Management 21: 67-87. [CrossRef]

Masip, Pere, Jaume Suau, and Carlos Ruiz-Caballero. 2020. Percepciones sobre medios de comunicación y desinformación: Ideología y polarización en el sistema mediático español. Profesional De La Información 29. [CrossRef]

Mazzoleni, Gianpietro, and Anna Sfardini. 2009. Politica pop. Da "Porta a Porta" a "L'isola dei famosi". Bologna: Il Mulino.

Muñiz, Carlos, Martín Echeverría, Alejandra Rodríguez-Estrada, and Oniel Francisco Díaz-Jiménez. 2018. Los hábitos comunicativos y su influencia en la sofisticación política ciudadana. Convergencia 25: 99-123. [CrossRef]

Navarro-Sierra, Nuria, and Raquel Quevedo-Redondo. 2020. El liderazgo político de la Unión Europea a través del ecosistema de aplicaciones móviles. Revista Prisma Social 30: 1-21. Available online: https:/ / bit.ly/3qyIVz4 (accessed on 24 June 2021).

Nye, Joseph S. 1990. Soft Power. Foreign Policy 80: 153-71. [CrossRef]

Penney, Joel. 2017. The Citizen Marketer: Promoting Political Opinion in the Social Media Age. New York: Oxford University Press.

Prada Espinel, Oscar, and Luis Miguel Romero Rodríguez. 2018. Polarización y demonización en la campaña presidencial de Colombia de 2018: Análisis del comportamiento comunicacional en Twitter de Gustavo Petro e Iván Duque. Revista Humanidades 9. [CrossRef]

Prior, Markus. 2006. Post-Broadcast Democracy: How Media Choice Increases Inequality in Political Involvement and Polarizes Elections. Cambridge: Cambridge University Press.

Quevedo-Redondo, Raquel, and Marta Portalés-Oliva. 2017. Imagen y comunicación política en Instagram. Celebrificación de los candidatos a la presidencia del Gobierno. El Profesional de la Información 26: 916-27. [CrossRef]

Raessens, Joost. 2014. The ludification of culture. In Rethinking Gamification. Edited by Mathias Fuchs, Sonia Fizek, Paolo Ruffino and Niklas Schrape. Lüneburg: Meson Press, pp. 91-114.

Rebolledo, Marta. 2017. La personalización de la política: Una propuesta de definición para su estudio sistemático. Revista de Comunicación 16: 147-76. [CrossRef]

Riffe, Daniel, Stephen Lacy, Brendan R. Watson, and Frederick Fico. 2014. Analyzing Media Messages. Using Quantitative Content Analysis in Research. New York: Routledge. [CrossRef]

Rojas, Hernando, and Eulalia Puig-i-Abril. 2009. Mobilizers Mobilized: Information, Expression, Mobilization and Participation in the Digital Age. Journal of Computer-Mediated Communication 14: 902-27. [CrossRef]

Romero-Rodríguez, Luis Miguel, Santiago Tejedor, and María Victoria Pabón Montealegre. 2021. Actitudes populistas y percepciones de la opinión pública y los medios de comunicación: Estudio correlacional comparado entre España y Colombia. Revista Latina De Comunicación Social 79: 43-66. [CrossRef]

Sandoval-Almazán, Rodrigo, Luis Luna-Reyes, Yaneileth Rojas-Romero, José Ramón Gil-Garcia, and Dolores Luna. 2012. Open Government 2.0: Citizen Empowerment through Open Data, Web and Mobile Apps. Paper presented at International Conference on Theory and Practice of Electronic Governance, Albany, NY, USA, October 22-25; pp. 30-33. [CrossRef]

Scherer, Chelsea. 2016. Civic engagement in a digital age. Canadian Parliamentary Review 39: 2-4.

Segado-Boj, Francisco, Jesús Díaz-Campo, and María Soria. 2015. La viralidad de las noticias en Facebook: Factores determinantes. Telos 100: 153-61.

Shankland, Stephen. 2008. Obama Releases iPhone Recruiting, Campaign Tool. [Blog Post]. Available online: https://cnet.co/2NL9IY6 (accessed on 24 June 2021).

Street, John. 1997. Politics and Popular Culture. Philadelphia: Temple University Press. 
Street, John. 2004. Celebrity politicians. Popular culture and political representation. The British Journal of Politics E International Relations 6: 435-52. [CrossRef]

Tau, Byron. 2012. Obama Campaign Launches Mobile App. [Blog Post]. Available online: https://politi.co/2p6bTaD (accessed on 24 June 2021).

Vázquez-Sande, Pablo. 2016. Políticapp: Hacia una categorización de las apps móviles de comunicación política. Fonseca Journal of Communication 12: 59-78. [CrossRef]

Wan, Xuqi, and Yucheng Shao. 2019. Innovative Research on the Interactive Communication of Political News in the Convergence Media Era by Taking the Newsgames Products of Mainstream Media for Example. The Frontiers of Society, Science and Technology 7: 111-17. [CrossRef]

Wang, Hai, Zhe Liu, Yao Guo, Chen Xiangqun, Zhang Miao, Xu Guoai, and Hong Jason. 2017. An Explorative Study of the Mobile App Ecosystem from App Developers' Perspective. International World Wide Web Conference Committee, 163-72. [CrossRef]

Wheeler, Mark. 2013. Celebrity Politics: Image and Identity in Contemporary Political Communication. Cambridge: Polity Press.

Williams, Raymond. 1993. Culture is Ordinary. In Studying Culture: An Introductory Reader. Edited by Ann Gray and Jim McGuigan. London: Arnold, pp. 5-14.

Wilson, Jason. 2011. Playing with politics: Political fans and Twitter faking in post-broadcast democracy. Convergence: The International Journal of Research into New Media Technologies 17: 445-61. [CrossRef]

Yamamoto, Masahiro, Matthew J. Kushin, and Francis Dalisay. 2018. How Informed Are Messaging App Users about Politics? A Linkage of Messaging App Use and Political Knowledge and Participation. Telematics E Informatics 35: 2376-86. [CrossRef]

Young, Sally. 2010. How Australia Decides: Election Reporting and the Media. Port Melbourne: Cambridge University Press.

Zamora-Medina, Rocío, José Carlos Losada-Díaz, and Pablo Vázquez-Sande. 2020. A taxonomy design for mobile applications in the Spanish political communication context. El Profesional de la Información 29. [CrossRef]

Zamora Medina, Rocío, Salvador Gómez García, and Helena Martínez Martínez. 2021. Los memes políticos como recurso persuasivo online. Análisis de su repercusión durante los debates electorales de 2019 en España. Opinião Publica 27: 1-24. 